\title{
Effect of Different Agroecosystem on Earthworm Diversity in Azaguié Locality (Côte d'Ivoire)
}

\author{
N'guetta Moïse Ehouman (Corresponding author) \\ Unité de Formation et de Recherche en science de la nature (UFR SN), Laboratoire \\ d'Ecologie et Développement Durable (LEDD), Université Nangui Abrogoua, Abidjan, Côte \\ d'Ivoire, 02 Bp 801 abidjan 02. E-mail: ehoumanmoise981@gmail.com

\section{Mamadou Touré} \\ Unité de Formation et de Recherche en science de la nature (UFR SN), Laboratoire \\ d'Ecologie et Développement Durable (LEDD), Université Nangui Abrogoua, Abidjan, Côte \\ d'Ivoire, 02 Bp 801 abidjan 02. E-mail: tourexham@gmail.com
}

Pkan pkan Kouakou Gains

Laboratoire National d'appui au Développement Rural (LANADA), Côte d'Ivoire.

E-mail: oraclegains@gmail.com

Hervé Kouya Bi

Unité de Formation et de Recherche en science de la nature (UFR SN), Laboratoire d'Ecologie et Développement Durable (LEDD), Université Nangui Abrogoua, Abidjan, Côte d'Ivoire, 02 Bp 801 abidjan 02. E-mail: kouyabiyouanherve@gmail.com

\section{Seydou Tiho}

Unité de Formation et de Recherche en science de la nature (UFR SN), Laboratoire d'Ecologie et Développement Durable (LEDD), Université Nangui Abrogoua, Abidjan, Côte d'Ivoire, 02 Bp 801 abidjan 02. E-mail: setiho@ hotmail.com

Received: Oct. 11, 2020 Accepted: Nov. 3, 2020

doi:10.5296/jbls.v11i2.17936 URL: https://doi.org/10.5296/jbls.v11i2.17936 


\section{Abstract}

In most terrestrial ecosystems, earthworms are considered to be excellent bioindicators of biodiversity and soil quality. However, their diversity and abundance encountered depend on the systems considered and on the anthropic pressure exerted. The objective of this study was to assess the impact of a land use on the earthworm community. Earthworms were collected in TSBF (Tropical Soil Biology and Fertility) type monoliths by the direct manual sorting method in three types of farms (fallow, rubber plantation and mangosteen plantation) in the locality of Azaguié. Measurements of the physicochemical parameters of the soil, in particular, the total organic carbon level, the organic matter rate, the nitrogen rate, the conductivity, the hydrogen potential $(\mathrm{pH})$ and the total phosphorus were carried out at the Laboratory Central of Agrochemistry and Ecotoxicology (LCAE) from $200 \mathrm{~g}$ of clod of soil sampled in different monoliths. These studies showed that in all the plots analyzed, the endogeic polyhumic worms presented the highest densities while the epigeic detritivorous worms presented the lowest densities. The distribution of earthworms in the mangosteen plot was homogeneous, unlike that of the other plots. However, the physico-chemical parameters of the soils were higher in the fallow. The canonical correspondence analysis carried out to assess the relationship between the variability of the earthworm density of the plots and the physicochemical parameters measured showed that the physicochemical parameters measured explained only a substantial part of this distribution of earthworms while the other part is possibly linked to other environmental factors.

Keywords: Earthworm, land use, physico-chemical parameters, Azaguié, bioindicators

\section{Introduction}

Environmental degradation due to inappropriate land use is a global problem that is becoming a growing concern in sustainable agricultural production systems (Ayoubi et al., 2011). Dynamic imbalances between the physical, chemical and biological properties of soils, which are continuously influenced by land use, lead to declines in productivity and sustainability (Somasundaram et al., 2013). In addition, many agricultural tillage activities have been identified as having irreversible consequences on the structure and dynamics of soil organisms such as earthworms, ants and termites (Montgomery, 2007; Evans et al., 2011). Yet these organisms play an important role in transforming the litter available for ecosystem functioning (Wardle, 2002). Among these organisms, earthworms are an important link in the functioning of the ecosystem (Lavelle and Spain, 2001). They are qualified as ecosystem engineers because of their great contribution to the recycling of biogeochemicals, which are the source of many ecosystem services (Lavelle et al., 2006). Indeed, these organisms participate in the decomposition of organic matter and the bioavailability of nutrients for plants and soil microorganisms. As well as contributing to the creation and maintenance of soil structure. Thus, their activities contribute to the maintenance of soil quality. Numerous studies have even shown that in ecosystems, their mode of distribution is conditioned by their relationship with plants, environmental parameters and human activities (Lavelle et al., 2006; Pelosi, 2008, Ehouman et al., 2014; Butt and Briones, 2017). Other studies carried out on farms have shown that earthworm densities are generally between 50 and 400 worms per 


\section{Macrothink Institute ${ }^{T M}$}

square meter, sometimes exceeding 1000 worms per square meter (Lee, 1985); the living biomass of earthworms is between 30 and 100 g per square meter (Lavelle and Spain, 2001) but can exceed $300 \mathrm{~g}$ per square meter (Lee, 1985)

In cultivated environments, the density and biomass of earthworms are generally very variable and the size of the populations is smaller than in natural environments, which generally harbour a very large number of earthworms (Edwards and Lofty, 2009). Given the importance of earthworms in agricultural practices, this study aims to assess the impact of some land-use patterns on the earthworm community in the Azaguié region.

\section{Materials and Methods}

\subsection{Study Site}

The present study was carried out in the locality of Azaguié, precisely in Abbè Begnini, a village located between $5^{\circ} 35$ and $6^{\circ} 15$ North latitude and $3^{\circ} 55$ and $4^{\circ} 40$ West longitude. The site exploited for this purpose had a surface area of about 30 hectares with a vegetation cover marked by an alternation of fallow land (more than 25 years), Mangosteen and rubber trees.

The soil in the study area is clay-sandy with a fairly constant texture. But most of the soils in this locality belong to the class of ferrallitic soils (ferralsols) developed on Birmian schist of the arkosic type or sometimes variegated schist rich in silica or green schist.

\subsection{Sampling Device}

For each type of farm (fallow, rubber tree and mangosteen tree), square sub-plots of $50 \mathrm{~m}$ each side were first delimited using a GPS of the Gamin brand. Each sub-plot was subdivided into 100 squares of $5 \mathrm{~m}$ each numbered from 1 to 100 . Then, within each subplot, a random draw without discount was carried out in order to choose 30 squares, each of which had a TSBF (Tropical Soil Biology and Fertility) type monolith $50 \mathrm{~cm}$ x $50 \mathrm{~cm}$ by $30 \mathrm{~cm}$ deep in its centre to collect earthworms and clods of soil (Figure 1).

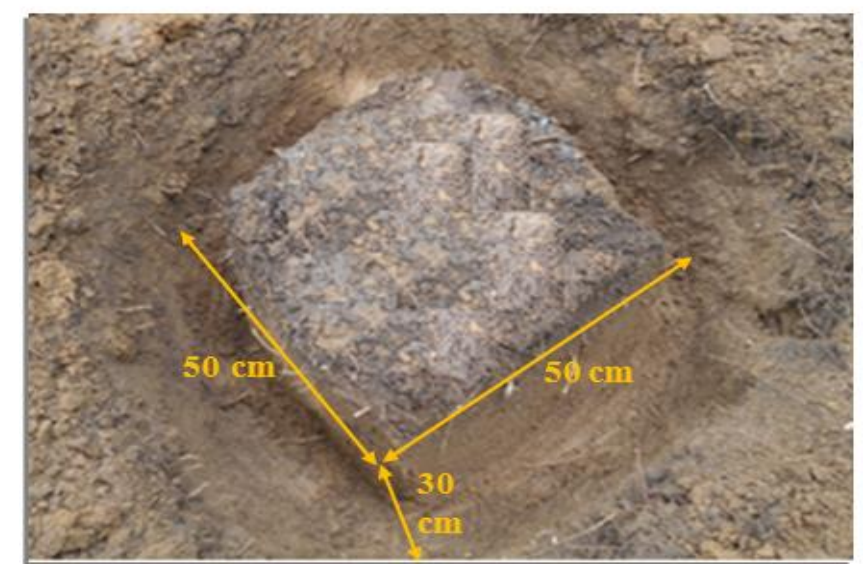

Figure 1. TSBF monolith 


\subsection{Collecting Earthworms and Soil Clods}

The earthworms were collected manually in the $0-10 \mathrm{~cm}, 10-20 \mathrm{~cm}$ and $20-30 \mathrm{~cm}$ strata using the method of (Lavelle, 1978). The worms were first stored in labelled jars containing 4\% diluted formaldehyde. The jars were then transported to the laboratory of the Centre de Recherche en Ecologie (CRE) where species identification was carried out using the determination keys in (Csuzdi and Tondoh, 2007), based on morphometrics (shape, size, length of segments) and pigmentation of the individuals. Soil samples were also taken at the level of each stratum using a trowel and then packed in carefully labelled stomacher bags. These clods of soil were kept in coolers equipped with carboglace, then sent to the Central Laboratory of Agrochemistry and Ecotoxicology (LCAE) for the determination of the physico-chemical parameters of the soil.

\subsection{Physico-Chemical Parameters}

The physico-chemical parameters of the soils were determined from $200 \mathrm{~g}$ of each clod of soil sampled, parameters such as total organic carbon $(\% \mathrm{CO})$, organic matter (\% OM), nitrogen $(\% \mathrm{~N})$, conductivity (Cond), hydrogen potential $(\mathrm{pH})$ and total phosphorus $(\mathrm{Pt})$.

Nitrogen was determined by the Kjeldahl method described in the French standard NFV04-407 (AFNOR, 2004). The mineraliser used was the Speedi- gesteur type (Buchi, Switzerland) and the distiller was type FB15025 (Fisher Scientific, USA). The conductivity was determined using the diluted extract method (Montoroi, 2017). The $\mathrm{pH}$ (water) of the soil was determined electrometrically using an HQ40d multimeter (Hach, USA), according to the $\mathrm{pH}$ determination protocol developed by the Centre d'Expertise en Analyse Environnementale du Québec (CEAEQ, 2003). Phosphorus was determined using the AOAC-958.01 method (AOAC, 1990). Phosphorus concentrations were determined using a UV/VIS spectrophotometer type UV Probe 1700 (Shimadzu, Japan).

Organic carbon and soil organic matter were determined by the fire loss method using a muffle furnace (Nabertherm, Germany) (CEAEQ, 2003; Hasine, 2008). The percentages of organic matter and organic carbon were obtained gravimetrically according to the following formula:

$$
\begin{aligned}
& \% \mathbf{M O}=\frac{\left[\left(\mathbf{M}_{\mathbf{0}}-\left(\mathbf{M}_{2}-\mathbf{M}_{1}\right)\right) \times \mathbf{1 0 0}\right]}{\mathbf{M}_{\mathbf{0}}} \\
& \% \mathbf{C O T}=\frac{\% \mathbf{M O}}{\mathbf{1 , 7 2 4}}
\end{aligned}
$$

Where:

M0: $5 \mathrm{~g}$ of soil sample completely dried in an incubator at $105^{\circ} \mathrm{C}$ for 48 hours;

M1: Platinum crucible mass (g);

M2: Crucible mass + the ash of the soil sample after incineration in a muffle furnace (Nabertherm, Germany) at $550^{\circ} \mathrm{C}$ for 4 hours (g);

MO: Organic matter; 
TOC: Total organic carbon;

1.724: conversion factor of organic matter to organic carbon.

\subsection{Statistical Analysis}

The distribution of the earthworm community across different land uses was assessed using the species richness and diversity index of Shannon and Weaver (Barbault ,1992) according to the following formula.

$$
H=-\sum_{\mathrm{i}=1}^{\mathrm{S}}\left(\frac{\mathrm{ni}}{\mathrm{N}}\right) \log _{2}\left(\frac{\mathrm{ni}}{\mathrm{N}}\right)
$$

Where:

S: Total number of species,

ni: Number of individuals of a species in the sample,

$\mathrm{N}$ : Total number of individuals of all species in the sample.

Equitability (E), which provides information on the distribution of numbers between the different species (Barbault,1992), was deduced. This is the ratio of actual diversity to maximum theoretical diversity and is expressed by the following equation:

$$
E=\frac{H}{\log _{2} S}=\frac{H}{H^{\prime} \max }
$$

Where:

E: Equitability,

H'max: maximum value that diversity can take,

S: total number of species.

The higher H' is, the higher H'max is and the greater the diversity. The higher $\mathrm{E}$ is, the more homogeneous the environment is with respect to the distribution of species. The value of this index varies from 0 to 1 ; it is maximum when the species have identical abundances in the stand, and minimum when a single species dominates the whole stand.

The one-factor analysis of variance (ANOVA) with repetition, followed by the Tukey test, was used to make pairwise comparisons between the physico-chemical parameters of the different plots. These tests were carried out using Xlstat Pro version 7.5 software.

Canonical Correspondence Analysis (CCA) was used to measure the links between the dependent variables (species density) and the explanatory variables (physico-chemical parameters) of each plot (fallow, mangosteen and rubber trees). The data were analyzing with Xlstat 2015.4.01 software. For all the statistical tests carried out, the significance threshold was set at $5 \%$. 


\section{1) Macrothink}

\section{Results and Discussion}

\subsection{Results}

\subsubsection{Abundance and Diversity of Earthworms}

A total of 12 earthworm species were collected (Agastrodrilus opisthogynus, Chuniodrilus zielae, Dichogaster agilis, Dichogaster baeri, Dichogaster ehrhardti, Dichogaster leroyi, Dichogaster saliens, Hyperiodrilus africanus, Millsonia ghanensis, Millsonia schlegelli, Stuhlmannia palustris and Stuhlmannia porifera). The Figure 2 shows some of the worm species found at the site.
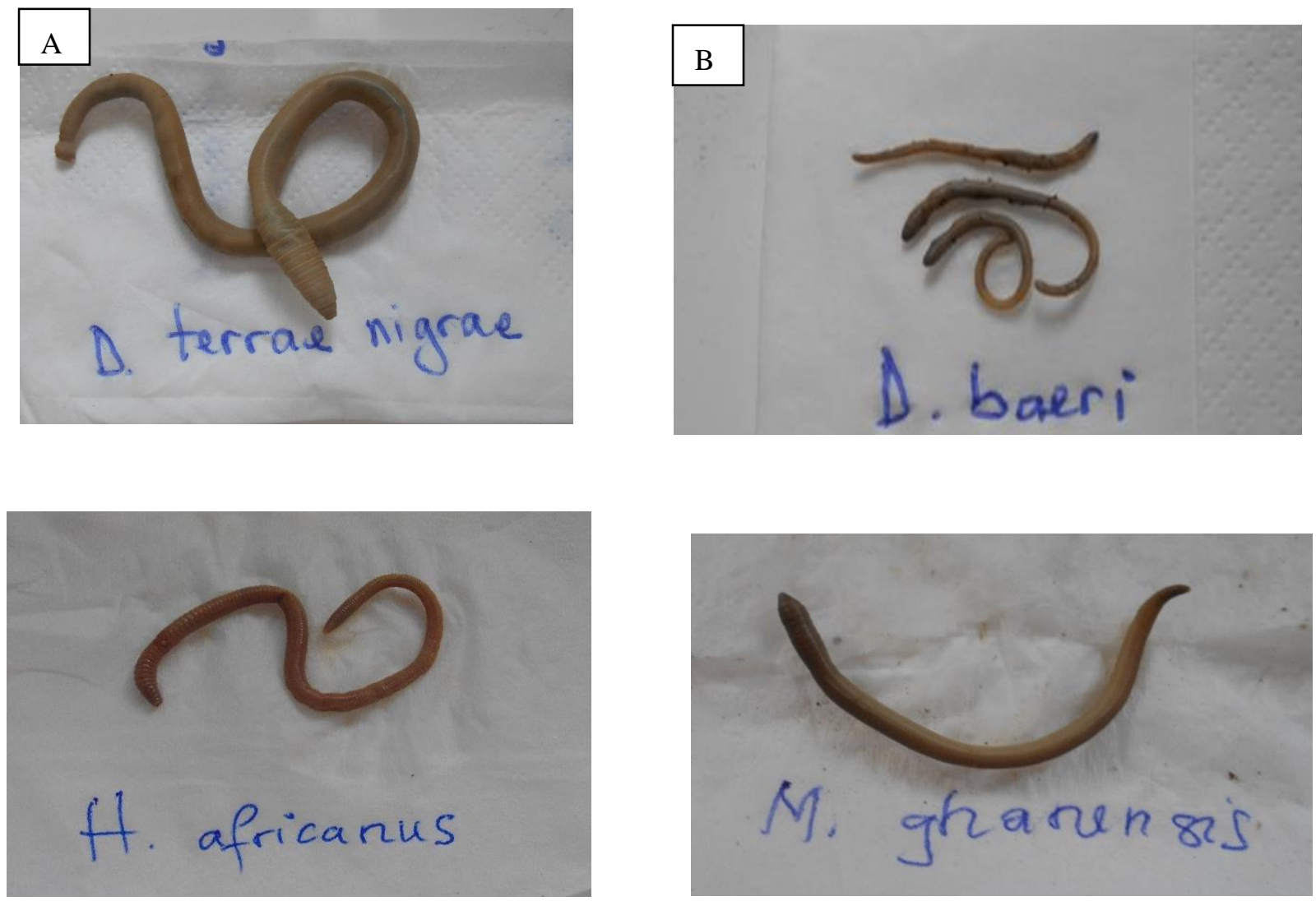

Figure 2. Photo of some of the earthworm species collected: A. Dichogaster terrae nigrae; B. Dichogaster baeri; C. Hyperiodrilus africanus; D. Millsonia ghanensis

All the species collected mainly belonged to three distinct ecological categories, namely oligohumic endogenous, polyhumic endogenous and detritivorous epigeae (Table 1). Of these species, the polyhumic endogeic worms Hyperiodrilus africanus, Chuniodrilus zielae, and Millsonia schlegelli had the highest densities, while the lowest densities were observed in the detritus-feeding epigea worms Dichogaster ehrhardti, Dichogaster baeri and Dichogaster saliens.

In all the plots, the highest worm densities were obtained in the $0-10 \mathrm{~cm}$ stratum $(11.56 \pm$ $0.88 \mathrm{ind} / \mathrm{m}^{2}$ (fallow); $37.00 \pm 0.90 \mathrm{ind} / \mathrm{m}^{2}$ (mangosteen) and $24.0 \pm 0.80 \mathrm{ind} / \mathrm{m}^{2}$ (rubber)) and the lowest densities were obtained in the $20-30 \mathrm{~cm}$ stratum $\left(0.05 \pm 0.00 \mathrm{ind} / \mathrm{m}^{2}\right.$ (fallow); 0.01 
$\pm 0.00 \mathrm{ind} / \mathrm{m}^{2}$ (mangosteen) and $0.03 \pm 0.00 \mathrm{ind} / \mathrm{m}^{2}$ (rubber)). However, for all strata, the abundance of earthworms was highest in Mangosteen soils, followed by Hevea soils and then fallow soils (Table 1). The Tuckey test used for the pairwise comparison of the strata indicated that at the $0-10 \mathrm{~cm}$ stratum, there was a significant difference between the worm densities in the mangosteen plot and those in the fallow and rubber tree plots $(\mathrm{P}<0.05)$. On the other hand, in the $10-20 \mathrm{~cm}$ and $20-30 \mathrm{~cm}$ strata, no significant difference was observed $(\mathrm{P}>0.05)$. Moreover, the Shannon-Weaver diversity index was greater for the mangosteen tree plot (2.81) than for the fallow (2.78) and rubber tree plots (2.61). Their respective equitabilities were $0.76,0.68$ and 0.64 (Table 2). This implies that the distribution of earthworm species was more homogeneous in the mangosteen plot than in the fallow and rubber tree plots.

Table 1. Density (ind $/ \mathrm{m}^{2}$ ) of earthworms harvested in the sampled plots (Fallow, Mangosteen and Rubber trees)

\begin{tabular}{|c|c|c|c|c|c|c|c|c|c|c|}
\hline & \multirow{2}{*}{$\begin{array}{l}\begin{array}{l}\text { Ecological } \\
\text { category }\end{array} \\
\end{array}$} & \multicolumn{3}{|c|}{ Fallow } & \multicolumn{3}{|c|}{ Mangosteen } & \multicolumn{3}{|c|}{ Rubber trees } \\
\hline & & $0-10 \mathrm{~cm}$ & $10-20 \mathrm{~cm}$ & $20-30 \mathrm{~cm}$ & $10 \mathrm{~cm}$ & $10-20 \mathrm{~cm}$ & $20-30 \mathrm{~cm}$ & $0-10 \mathrm{~cm}$ & $10-20 \mathrm{~cm}$ & $20-30 \mathrm{~cm}$ \\
\hline $\begin{array}{l}\text { Agastrodrilus } \\
\text { opisthogynus }\end{array}$ & $\begin{array}{l}\text { Endogeic } \\
\text { oligohumic }\end{array}$ & $0.15 \pm 0.00$ & $0.03 \pm 0.00$ & $0.00 \pm 0.00$ & $0.85 \pm 0.02$ & $0.01 \pm 0.00$ & $0.00 \pm 0.00$ & $1.05 \pm 0.04$ & $0.05 \pm 0.00$ & $0,00 \pm 0.00$ \\
\hline $\begin{array}{l}\text { Chuniodrilus } \\
\text { zielae }\end{array}$ & $\begin{array}{l}\text { Endogeic } \\
\text { polyhumic }\end{array}$ & $2.35 \pm 0.03$ & $0.30 \pm 0.10$ & $0.01 \pm 0.00$ & $8.48 \pm 0.20$ & $0.35 \pm 0.00$ & $0.00 \pm 0.00$ & $3.00 \pm 0.10$ & $0.15 \pm 0.04$ & $0.01 \pm 0.00$ \\
\hline $\begin{array}{l}\text { Dichogaster } \\
\text { agilis }\end{array}$ & $\begin{array}{l}\text { Epigeic } \\
\text { detritivorous }\end{array}$ & 2 & 01 & $\overline{0}$ & $\overline{06}$ & 0 & 0 & .05 & 0.00 & $.01 \pm 0.00$ \\
\hline $\begin{array}{l}\text { Dichogaster } \\
\text { baeri }\end{array}$ & $\begin{array}{l}\text { Epigeic } \\
\text { detritivorous }\end{array}$ & $0.00 \pm 0.00$ & $0.00 \pm 0.00$ & 0.00 & .02 & $0.02 \pm 0.01$ & $0.00 \pm 0.00$ & $0.75 \pm 0.07$ & $0.00 \pm 0.00$ & $0.00 \pm 0.00$ \\
\hline $\begin{array}{l}\text { Dichogaster } \\
\text { ehrhardti }\end{array}$ & orous & 0.00 & 0.00 & .00 & $0.00 \pm 0.00$ & $=0.00$ & $=0.00$ & $1.45 \pm 0.10$ & $0.00 \pm 0.00$ & $0.00 \pm 0.00$ \\
\hline $\begin{array}{l}\text { Dichogaster } \\
\text { leroyi }\end{array}$ & $\begin{array}{l}\text { Epigeic } \\
\text { détritivorous }\end{array}$ & $0.11 \pm 0.10$ & $0.10 \pm 0.02$ & $0.00 \pm 0.00$ & $0.03 \pm 0.01$ & $0.00 \pm 0.00$ & $0.00 \pm 0.00$ & $0.75 \pm 0.04$ & $0.04 \pm 0.20$ & $0.00 \pm 0.00$ \\
\hline $\begin{array}{l}\text { Dichogaster } \\
\text { saliens }\end{array}$ & $\begin{array}{l}\text { Epigeic } \\
\text { détritivorous }\end{array}$ & $0.15 \pm 0.00$ & $0.01 \pm 0.01$ & $0.00 \pm 0.00$ & $0.14 \pm 0.00$ & $0.01 \pm 0.00$ & $0.00 \pm 0,00$ & $0.75 \pm 0.06$ & $0.00 \pm 0.00$ & $0.00 \pm 0.00$ \\
\hline $\begin{array}{l}\text { Hyperiodrilus } \\
\text { africanus }\end{array}$ & $\begin{array}{l}\text { Endogeic } \\
\text { polyhumic }\end{array}$ & $4.16 \pm 0.04$ & $0.59 \pm 0.13$ & $0.02 \pm 0.00$ & $12.66 \pm 0.30$ & $0.40 \pm 0.01$ & $0.01 \pm 0.00$ & $6.35 \pm 0.13$ & $0.30 \pm 0.00$ & $0.02 \pm 0.00$ \\
\hline $\begin{array}{l}\begin{array}{l}\text { Millsonia } \\
\text { ghanensis }\end{array} \\
\end{array}$ & $\begin{array}{l}\text { Endogeic } \\
\text { polyhumic }\end{array}$ & $0.25 \pm 0.03$ & $0.1 \pm 0.02$ & $0.00 \pm 0.00$ & $1.17 \pm 0.06$ & $0.07 \pm 0.00$ & $0,00 \pm 0.00$ & $0.75 \pm 0.04$ & $0.07 \pm 0.00$ & $0.00 \pm 0.00$ \\
\hline $\begin{array}{l}\text { Millsonia } \\
\text { schlegelli }\end{array}$ & Endogeic & $2.05 \pm 0.01$ & $1.15 \pm 0.05$ & $0.01 \pm 0.00$ & $4.34 \pm 0.10$ & $0.15 \pm 0.00$ & $0.00 \pm 0.00$ & $3.00 \pm 0.10$ & $0.15 \pm 0.00$ & $0.00 \pm 0.00$ \\
\hline $\begin{array}{l}\text { Stuhlmannia } \\
\text { palustris }\end{array}$ & Endogeic & $0.30 \pm 0.01$ & $0.1 \pm 0.02$ & $0.00 \pm 0.00$ & $1.69 \pm 0.03$ & $0.08 \pm 0.01$ & $0.00 \pm 0,00$ & $0.75 \pm 0.04$ & $0.03 \pm 0.00$ & $0.00 \pm 0.00$ \\
\hline $\begin{array}{l}\text { Stuhlmannia } \\
\text { porifera }\end{array}$ & $\begin{array}{l}\text { Endogeic } \\
\text { polyhumic }\end{array}$ & $0.30 \pm 0.01$ & $0.05 \pm 0.01$ & $0.01 \pm 0.00$ & $2.40 \pm 0.10$ & $0.05 \pm 0.00$ & $0.00 \pm 0.00$ & & $0.03 \pm 0.00$ & $0.00 \pm 0.00$ \\
\hline Total & & $11.56 \pm 0.88$ & $2.5 \pm 0.36$ & $0.05 \pm 0.00$ & $37.00 \pm 0.90$ & $1.33 \pm 0.20$ & $\begin{array}{l}0.01 \pm 0.00 \\
\end{array}$ & $24.0 \pm 0.80$ & $0.81 \pm 0.24$ & $0.03 \pm 0.00$ \\
\hline
\end{tabular}


Table 2. Shannon-Weaver diversity index and equitability of earthworms in the plots (fallow, mangosteen and rubber trees)

\begin{tabular}{l|c|c|c}
\hline & $\mathrm{H}$ & H'max & $\mathrm{E}$ \\
\hline Fallow & 2.78 & 4.32 & 0.64 \\
\hline Mangosteen & 2.81 & 3.7 & 0.76 \\
\hline Rubber trees & 2.61 & 3.8 & 0.68 \\
\hline
\end{tabular}

\subsubsection{Physico-Chemical Parameters of Soils}

In general, the values of the different physico-chemical parameters determined in the sampled plots (fallow, mangosteen and rubber trees) were higher in the $0-10 \mathrm{~cm}$ stratum and lower in the 20-30 cm stratum, Thus:

- Organic matter $(\mathrm{OM})$, average rates ranged from $8.01 \pm 0.24 \%(0-10 \mathrm{~cm}$ stratum $)$ to $5.10 \pm$ $0.20 \%(20-30 \mathrm{~cm})$ for the fallow plot, from $4.85 \pm 0.23 \%(0-10 \mathrm{~cm}$ stratum) to $3,41 \pm 0.17 \%$ $(20-30 \mathrm{~cm})$ for the mangosteen plot, and from $5.98 \pm 0.34 \%(0-10 \mathrm{~cm}$ stratum) to $4.13 \pm$ $0.22 \%(20-30 \mathrm{~cm})$ for the rubber plot (Table 3). Pair comparisons using the Tuckey's test indicated that the mean organic matter levels at the strata level of the different plots were statistically different $(\mathrm{p}<0.05)$.

- $\mathrm{pH}$, the average values were on the whole acidic and almost constant. They varied from 5.72 $\pm 0.20(0-10 \mathrm{~cm}$ stratum $)$ to $5.62 \pm 0.20(20-30 \mathrm{~cm}$ stratum $)$ in the fallow plot, from $5.33 \pm$ $0.10(0-10 \mathrm{~cm}$ stratum $)$ to $5.26 \pm 0.20(20-30 \mathrm{~cm}$ stratum $)$ in the mangosteen plot, and from $5.6 \pm 0.15(10-30 \mathrm{~cm}$ stratum) to $5.5 \pm 0.10(20-30 \mathrm{~cm}$ stratum) in the rubber plot (Table 3$)$. Tuckey's test indicated that the mean $\mathrm{pH}$ values were statistically identical at both stratum and plot level $(\mathrm{p}<0.05)$.

- Conductivity, mean rates ranged from $116 \pm 8.74 \mu \mathrm{S} / \mathrm{cm}(0-10 \mathrm{~cm}$ stratum) to $41.60 \pm 3.28$ $\mu \mathrm{S} / \mathrm{cm}(20-30 \mathrm{~cm}$ stratum) at the fallow plot, from $64.74 \pm 4.52 \mu \mathrm{S} / \mathrm{cm}(0-10 \mathrm{~cm}$ stratum) to $48,33 \pm 3.49 \mu \mathrm{S} / \mathrm{cm}$ (stratum $20-30 \mathrm{~cm}$ ) at the mangosteen plot and from $67.51 \pm 5.23 \mu$ $\mathrm{S} / \mathrm{cm}$ (stratum $0-10 \mathrm{~cm}$ ) to $30.04 \pm 1.76 \mu \mathrm{S} / \mathrm{cm}$ (stratum $20-30 \mathrm{~cm}$ ) at the rubber plot (Table 3 ). Tuckey's test indicated that at the level of the different strata, only the conductivity of the fallow plot was significantly different from the average rates of the mangosteen and rubber plots $(\mathrm{P}<0.05)$.

- Total phosphorus (pt), mean levels ranged from $13.76 \pm 1.0 \mathrm{mg} / \mathrm{kg}(0-10 \mathrm{~cm}$ stratum) to $13.19 \pm 0.93 \mathrm{mg} / \mathrm{kg}(20-30 \mathrm{~cm}$ stratum) at the fallow plot, from $16.53 \pm 1.44 \mathrm{mg} / \mathrm{kg}(0-10 \mathrm{~cm}$ stratum) to $15,81 \pm 1.59 \mathrm{mg} / \mathrm{kg}$ (stratum $20-30 \mathrm{~cm}$ ) at the mangosteen plot and from $13.73 \pm$ $1.16 \mathrm{mg} / \mathrm{kg}$ (stratum $0-10 \mathrm{~cm}$ ) to $11.50 \pm 0.9 \mathrm{mg} / \mathrm{kg}$ (stratum $20-30 \mathrm{~cm}$ ) at the rubber plot (Table 3). Tuckey's test indicated that, at all strata, the average phosphorus levels in the mangosteen plots differed significantly from those in the other plots $(\mathrm{P}<0.05)$. However, between the fallow and rubber tree plots, the mean phosphorus levels in the $0-10 \mathrm{~cm}$ stratum did not differ significantly $(\mathrm{P}>0.05)$.

- $\mathrm{C} / \mathrm{N}$ ratio, mean values ranged from $8.53 \pm 0.57(0-10 \mathrm{~cm}$ stratum $)$ to $6.4 \pm 0.37(20-30 \mathrm{~cm})$ at the fallow plot, from $6.23 \pm 0.51(0-10 \mathrm{~cm}$ stratum $)$ to $4,71 \pm 0.26(20-30 \mathrm{~cm})$ at the mangosteen plot and from $6.23 \pm 0.51(0-10 \mathrm{~cm}$ stratum $)$ to $4.71 \pm 0.26(20-30 \mathrm{~cm})$ at the 
rubber plot (Table 3). Tuckey's test indicated that at the $0-10 \mathrm{~cm}$ stratum, the $\mathrm{C} / \mathrm{N}$ ratio values of the different plots differed significantly $(\mathrm{P}<0.05)$ with a predominance of fallow plot values. However, at the $10-20 \mathrm{~cm}$ and $20-30 \mathrm{~cm}$ level, there is no significant difference between the $\mathrm{C} / \mathrm{N}$ ratio values of the different plots $(\mathrm{P}>0.05)$.

Table 3. Physico-chemical parameters of the soils in the sampled plots (fallow, mangosteen and rubber tree)

\begin{tabular}{|c|c|c|c|c|c|c|c|c|c|}
\hline & \multicolumn{3}{|c|}{$0-10 \mathrm{~cm}$} & \multicolumn{3}{|c|}{$10-20 \mathrm{~cm}$} & \multicolumn{3}{|c|}{$20-30 \mathrm{~cm}$} \\
\hline & Fallow & Mangosteen & $\begin{array}{l}\text { Rubber } \\
\text { trees }\end{array}$ & Fallow & Mangosteen & $\begin{array}{l}\text { Rubber } \\
\text { trees }\end{array}$ & Fallow & Mangosteen & $\begin{array}{l}\text { Rubber } \\
\text { trees }\end{array}$ \\
\hline$\% \mathrm{OM}$ & $8.01 \pm 0,24$ & $4.85 \pm 0.23$ & $5.98 \pm 0.34$ & $5.53 \pm 0.20$ & $3.64 \pm 0.10$ & $4.51 \pm 0.24$ & $5.10 \pm 0.20$ & $3.41 \pm 0.17$ & $4.13 \pm 0.22$ \\
\hline pH & $5.72 \pm 0.20$ & $5.33 \pm 0.10$ & $5.6 \pm 0.15$ & $5.62 \pm 0.20$ & $5.26 \pm 0.10$ & $5.48 \pm 0.10$ & $5.62 \pm 0.20$ & $5.26 \pm 0.10$ & $5.50 \pm 0.10$ \\
\hline Cond & & & & & & & & & \\
\hline$(\mu \mathrm{S} / \mathrm{cm})$ & $116 \pm 8.74$ & $64.74 \pm 4.52$ & $67.51 \pm 5.23$ & $56 \pm 3.80$ & $43.82 \pm 3.80$ & $41.60 \pm 3.28$ & $48.33 \pm 3.49$ & $33.14 \pm 2.20$ & $30.04 \pm 1.76$ \\
\hline Pt (mg/kg) & $13.76 \pm 1.0$ & $15.81 \pm 1.59$ & $13.73 \pm 1.16$ & $11.65 \pm 0.90$ & $17.02 \pm 1.64$ & $16.53 \pm 1.44$ & $13.19 \pm 0.93$ & $16.53 \pm 1.44$ & $11.50 \pm 0.9$ \\
\hline$\% \mathrm{~N}$ & $0.60 \pm 0.20$ & $0.49 \pm 0.10$ & $0.52 \pm 0.03$ & $0.60 \pm 0.10$ & $0.52 \pm 0.10$ & $0.58 \pm 0.34$ & $0.49 \pm 0.10$ & $0.43 \pm 0.10$ & $0.45 \pm 0.02$ \\
\hline$\% \mathrm{C}$ & $4.65 \pm 0.10$ & $2.76 \pm 0.10$ & $3.47 \pm 1.07$ & $3.21 \pm 0.10$ & $2.12 \pm 0.10$ & $2.62 \pm 0.50$ & $3.47 \pm 0.10$ & $1.98 \pm 0.10$ & $2.40 \pm 0.60$ \\
\hline $\mathrm{C} / \mathrm{N}$ & $8.59 \pm 0.60$ & $6.23 \pm 0.40$ & $7.17 \pm 0.50$ & $5.73 \pm 0.40$ & $4.37 \pm 0.40$ & $5.00 \pm 0.40$ & $6.40 \pm 0.37$ & $4.71 \pm 0.30$ & $5.63 \pm 0.43$ \\
\hline
\end{tabular}

OM: Organic matter; Cond: Conductivity; Pt: Total phosphorus; N: Nitrogen; C: Carbon

\subsubsection{Interaction Between Earthworms and Physico-Chemical Parameters}

Canonical correspondence analysis (CCA) showed that the physico-chemical parameters (organic matter, $\mathrm{pH}$, conductivity, total phosphorus and $\mathrm{C} / \mathrm{N}$ ratio) explain only a small part of the variability in earthworm density in each of the plots $(23.90 \%, 16.62 \%$ and $42.47 \%$ of the total inertia respectively in the fallow, mangosteen and rubber tree plots) (Table 4a; $4 \mathrm{~b}$ and $4 \mathrm{c}$ ). Thus, the variability in earthworm density in the fallow, mangosteen and rubber tree plots is mainly linked to environmental parameters other than the physico-chemical parameters determined $(76.10 \%, 83.38 \%$ and $57.53 \%$ of the total inertia respectively at the level of the fallow, mangosteen and rubber tree plots) (Tables $4 \mathrm{a}, 4 \mathrm{~b}$ and $4 \mathrm{c}$ ). The Monte Carlo permutation test indicated that for each plot the canonical axes were not a linear combination of environmental parameters $(\mathrm{p}=0.751>5 \% ; \mathrm{p}=0.964>5 \%$ and $\mathrm{p}=0.832>$ $5 \%$ for fallow, mangosteen and rubber trees plots respectively).

Table 4a. Distribution of inertia at the fallow plot level

\begin{tabular}{lcc}
\hline & value & $\%$ \\
\hline Total & 2.1 & 100.00 \\
Constraint & 0.7 & $\mathbf{2 3 . 9 0}$ \\
Non-constraint & 1.43 & $\mathbf{7 6 . 1 0}$ \\
\hline
\end{tabular}


Table $4 \mathrm{~b}$. Distribution of inertia at the mangosteen plot level

\begin{tabular}{lcc}
\hline & Value & $\%$ \\
\hline Total & 1,41 & 100.00 \\
Constraint & 0.38 & $\mathbf{1 6 . 6 2}$ \\
Non-constraint & 1.03 & $\mathbf{8 3 . 3 8}$ \\
\hline
\end{tabular}

Table 4c. Distribution of inertia at the level of the rubber plot

\begin{tabular}{ccc}
\hline & Value & $\%$ \\
\hline Total & 2.54 & 100.00 \\
Contraint & 0.83 & $\mathbf{4 2 . 4 7}$ \\
Non-constraint & 1.71 & $\mathbf{5 7 . 5 3}$ \\
\hline
\end{tabular}

\subsection{Discussion}

For all the plots analysed, polyhumic endogenous worms had the highest densities. while detritus-feeding epigeic worms had the lowest densities. The difference in density observed between these categories of earthworms is due, on the one hand, to the fact that they exploit different horizons for collecting their food and, on the other hand, to the constraints specific to their survival environment. Indeed, polyhumic endogenous worms generally live in the first few centimeters of soil. They thus build a network of sub-horizontal galleries from which they consume soil from superficial horizons rich in decomposing organic matter (Brown et al., 2000). This shelters them from the bad weather linked to the constraints of the environment. However, detritivorous epigeic worms live in the surface litter and feed on decomposing organic matter (Brown et al., 2000; Pelosi et al., 2008). As a result, they are the most exposed to climatic hazards, predation and cultural operations such as tillage and pesticide use. These factors adversely affect their diversity, density and biomass in the cultivated environment (Smeaton et al., 2003). The distribution of earthworms in the mangosteen plot was homogeneous, unlike that of the other plots. This reflects an accelerated mineralization of the organic matter produced by the leaves and twigs of the plant. This favours an increase in worm density (Cluzeau, 2005). On the other hand, the low diversity and abundance of earthworms in the fallow plot could be due to the importance of the diversity of fauna and flora, which could favour the presence of numerous predators and competitors (termites, ants...). Indeed, these predators have a negative impact on the density and distribution of earthworms during the search for food (Dominguez et al., 2001). Also, the presence of large roots due to the non-exploitation of this environment would prevent the creation of galleries (Houseman et al., 2000). Furthermore Lavelle et al. (2006), describing 
the dynamics of a worm population, concluded that in cultivated systems, rainfall and soil moisture are the elements that would most significantly influence the dynamics of the worm population. Temperature and light are therefore not excluded from the factors that could explain the difference in earthworm diversity observed between the three plots.

However, the average values of the physico-chemical parameters were higher in the fallow land. This could be explained by the stability of this ecosystem. However, in this environment, the stock of organic matter was poorly used by the plants. This is contrary to the cultivated environment, where organisms exploit this matter. The result is an increase in the density of earthworms, which could modify the physical properties of the soil (Cluzeau et al., 1987). Agricultural practices that could influence earthworms are ploughing and the use of pesticides (Chan et al., 2001, Thomas, 2004, Pelosi et al., 2014). But in this study, tillage was excluded because it was not used in the establishment and maintenance of mangosteen and rubber plantations. Nevertheless, a $\mathrm{C} / \mathrm{N}$ ratio of less than 15 in the soils of these three plots would mean accelerated decomposition of organic matter. This rapid mineralisation of organic matter could be a corollary of intense biological activities in the soil (Soltner, 2000). These observations are contrary to recent studies which have shown a $\mathrm{C} / \mathrm{N}$ ratio higher than 50 in the Azaguié locality, which would indicate a slow mineralisation of organic matter at soil level (Kouamé et al., 20014; N'guessan, 20014). Among the physico-chemical parameters, the $\mathrm{pH}$ values showed that the three plots had acidic soils in the light of the $\mathrm{pH}$ scale commonly used by laboratories (Zro Bi, 2012). These $\mathrm{pH}$ values were relatively higher than the $\mathrm{pH}$ values (4.7-5) obtained by Kabrah et al. (2000) for the soils under palm groves in the Mé region (Côte d'Ivoire). Moreover, the $\mathrm{pH}$ values of the present study are very close to those for Kouamé (2014) where the $\mathrm{pH}$ values were between 5.22 and 5.39 for the soils of Yamoussoukro, and between 5.90 and 6.00 for the soil of Azaguié. The results of these authors also confirm the near constancy of the $\mathrm{pH}$ up to $30 \mathrm{~cm}$ depth. Finally, the acidic character of the Azaguié soils was also reported by (Bi Voko et al., 2013) who recorded pH values < 5.17. Studies carried out by (Singh and Schluze, 2015) showed that mineralization of organic matter would release mineral elements in the soil in ionic form in solution. In addition, the mangosteen, rubber and fallow plots had soils with low total phosphorus content according to the classification scale of the "Comité d'Etude et de Development de la Fertilisation" (COMIFER) (Vedie, 2008). These total phosphorus contents were lower than those obtained by Kouamé (2014), who found total phosphorus concentrations of 229.08 $\mathrm{mg} / \mathrm{kg}$ and $214.75 \mathrm{mg} / \mathrm{kg}$ respectively for the $0-20 \mathrm{~cm}$ and $20-40 \mathrm{~cm}$ strata of the Azaguié soil. This difference could be due to plant cover and agronomic exploitation. Indeed, these values were obtained on a dense forest soil whereas our study site presented soils in exploitation (mangosteen and rubber tree plots) and a 25 years old fallow.

The variability in earthworm density in the plots analysed (fallow, mangosteen and rubber trees) was explained in part by the physico-chemical parameters (organic matter, $\mathrm{pH}$, conductivity, total phosphorus and $\mathrm{C} / \mathrm{N}$ ratio). This would be due to the low percentages of CCA inertia that provide information on this relationship (26.67\% and $32.87 \%$ respectively for the mangosteen and fallow plots). This suggests that environmental parameters, such as the physico-chemical parameters used in the CCA, are involved in the variability of worm 
density in the different plots. At the fallow level, parameters such as humidity, temperature and light could be impacted by the variation in worm density. According to Edwards and Bohlen (1996) and Faurie et al. (2012), these factors greatly influence the life of these organisms. Concerning mangosteen and rubber tree plots, in addition to humidity, temperature, and light, agricultural practices, specifically the use of pesticides such as herbicides, could probably impact on the survival of earthworms because they are much more sensitive to them (Chan, 2001; Thomas, 2004). Indeed, according to observations, the use of glyphosate and 2,4-D herbicides has been the preferred method of weed control on these farms for more than 10 years. Thus, the contribution of these herbicides to influencing the survival of earthworms cannot be excluded because of the notorious toxicity of herbicides formulated on earthworms. To this end, the work of Zarea and karimi (2011); Kpan kpan (2017) and Kpan Kpan et al. (2018) has shown an increased toxicity of glyphosate and 2,4-D herbicides in earthworms, particularly in the species Eudrilus eugeniae. These herbicides significantly reduce egg-laying, the rate of cocoon hatching and the number of juveniles produced from each.

\section{Conclusion}

The present study has shown that polyhumic endogenous worms seem to be the most adapted to the different modes of land use in the locality of Azaguié. For the farms analysed (fallow, mangosteen and rubber trees), the mangosteen plot was favourable to the development and distribution of worm communities. The physico-chemical parameters of the soil, particularly organic matter, $\mathrm{pH}$, conductivity, total phosphorus and $\mathrm{C} / \mathrm{N}$ ratio, were well illustrated in the fallow plot. Moreover, in all the plots, the survival and distribution of earthworms seemed to be affected by other environmental factors. The survival of earthworms on a farm would therefore depend on the plants that are cultivated there and the farming practices.

\section{Acknowledgements}

We would like to thank the anonymous reviewers and the Laboratory Central of Agrochemistry and Ecotoxicology (LCAE) for analysing soil data.

\section{Conflict of authors}

No conflict of interest

\section{References}

AFNOR. (2004). Détermination de l'azote total et calcul de la teneur en protéines. Norme française, NF-V04-407, p. 14.

AOAC. (1990). Official methods of analysis (volume1). 15th édition, Washington, p. 771.

Ayoub, S. I., Khormali, F., Sahrawat, K. L., \& Rodrigues de Lima, A. C. (2011). Assessing impacts of land use change on soil quality indicators in a loessial soil in Golestan province, Iran. Journal of Agricultural Science and Technology, 13, 727-742. https://jast.modares.ac.ir/article-23-11795-en.pdf

Barbault, R. (1992). Écologie des peuplements, structure, dynamique et évolution. Masson, 
Paris, p. 273. https://onlinelibrary.wiley.com/doi/abs/10.1046/j.1420-9101.1993.6040611.x

Bi Voko, D. R. R., Niamké, Z. S. L., \& Zézé, A. (2013). Impact des propriétés physico-chimiques des sols de culture du manioc sur l'abondance et la diversité des communautés de champignons mycorhiziens à arbuscules dans la zone agroécologique d'Azaguié, Sud-Est de la Côte d'ivoire. Agronomie Africaine, 25(3), 251-2.

Brown, G. G., Baroisa, I., \& Lavelle, P. (2000). Regulation of soil organic matter dynamics and microbial activity in the drilosphere and the role of interactions with other edaphic functional domains. European Journal of Soil Biology: 36(3), 177-198. https://horizon.documentation.ird.fr/exl-doc/pleins_textes/pleins_textes_7/b_fdi_57-58/01002 4175.pdf

Butt, K. R., \& Briones, M. J. I. (2017). Earthworms and mesofauna from an isolated, alkaline chemical waste site in Northwest England. European Journal of Soil Biology, 78, 43-49. https://doi.org/10.1016/j.ejsobi.2016.11.005

CEAEQ. (2003). Détermination de la matière organique par incinération: méthode de perte au feu (PAF). MA. 1010-PAF 1.0. Ministère de l'Environnement du Québec, p. 9.

CEAEQ. (2003). Détermination du $\mathrm{pH}$ à l'eau et du $\mathrm{pH}$ tampon dans les sols agricoles: méthode électrométrique. MA. 205-pH 1.0. Ministère de l'Environnement du Québec, p. 13.

Chan, K. Y. (2001). An overview of some tillage impacts on earthworm population abundance and diversity - implications for functioning in soils. Soil \& Tillage Research, 57(4), 179-191.

Cluzeau, D. (2005). Restauration de fonctions et propriétés des sols de grande culture intensive. Effets de systèmes de culture alternatifs sur les matières organiques et la structure des sols limoneux, et approche du rôle fonctionnel de la diversité biologique des sols. Rapport final du projet Dmostra, Subvention $n^{\circ}$ 01105, Programme GESSOL $n^{\circ}$ A01494. Ministère de l'Écologie et du Développement Durable, p. 119.

Cluzeau, D., Lebouvier, M., Tehen, P., Bouché, M. B., Badour C., \& Perraud, A. (1987) Relations between earthworms and agricultural practices in the vineyards of Champagne. Preliminary results. On Earthworms. Mucchi, Modena, pp. 465-484.

Csuzdi, C. \& Tondoh, J. E. (2007). New and little-known earthworm species from the Ivory Coast (Oligochaeta: Acanthodrilidae: Benhamiinae and Eudrilidae). Journal of National History, 41, 2551-2567. https://doi.org/10.1080/00222930701742629

Dominguez, J., Edwards, C. A., \& Ashby, J. (2001). The biology and population dynamics of Eudrilus eugeniae (Kinberg) (Oligochaeta) in cattle waste solids. Pedobiologia, 45, 341-353. https://citeseerx.ist.psu.edu/viewdoc/download?doi=10.1.1.1061.2696\&rep=rep1\&type=pdf

Edwards, C. A., \& Bohlen P. J. (1996). Biology and ecology of earthworms. Chapman and Hall, London, p. 426. https://www.springer.com/gp/book/9780412561603

Edwards, C. A., \& Lofty, J. R. (1979). The effects of straw residues and their disposal on the soil fauna. In: Willey, E. (eds), Straw decay and its effect on dispersal and utlization. New York, 
pp. 37-44.

Ehouman, N. M., Tiho S., \& Dagnogo, M. (2014). Etude des interactions spatiales entre vers de terre et couvert végétal de trois surface-échantillons dans les savanes de Lamto (Côte d'Ivoire), Thèse de l’Université Nangui Abrogoua. P117.

Evans, T. A., Dawes, T. Z., P. R., \& Ward, N. Lo. (2011). Ants and termites increase crop yield in a dry climate. Nature Communications, 2, 262. https://doi.org/10.1038/ncomms1257 (2011).

Faurie, C., Ferra C., Médori P., Devaux J., \& Hemptinne L. J. (2012). Ecologie: Approche scientifique et pratique. Tec \& Doc Lavoisier, Paris, 6è édition, pp. 191-194.

Hasine, B. H., Aloui, T., Gallali, T., Bouzid, T., El Amri, S., \& Hassen, B. R. (2008). Evaluation quantitative et rôle de la matière organique dans les sols cultivés en zones subhumides et semiarides méditerranéenne de la Tunisie. Agrosolutions, 19(2), 4-17.

Houseman, J. G. (2000). Les annélides. BIO 2521. Université d'Ottawa, Canada, p. 14.

Kabrah, Y., Koffi, B. (2000). Caractéristiques chimiques des sols sous palmeraie. Cahiers Agricultures, 9(1), 73-76.

Kouamé, N., Dick, A. E., Assidjo, N. E., \& Anno, A. P. (2014). Etude de la croissance du bananier plantain (Musa sp., AAB, cultivar Corne 1) dans les régions de Yamoussoukro et Azaguié (Côte d'Ivoire). Journal of Applied Biosciences, 76(64), 11-6424. http://www.m.elewa.org/JABS/2014/76/11.pdf

Kpan Kpan, K. G., Ehouman, N. M., Touré, M., Yao, B. L., Tiho, S., Traoré, K. S., \& Dembélé, A. (2018). Toxicité d'un herbicide à base de glyphosate sur le ver de terre Eudrilus Eugeniae KINBERG, 1867 (Oligochaeta, Eudrilidae). European Journal of Scientific Research, 150(3), 285-298. https://www.europeanjournalofscientificresearch.com/issues/PDF/EJSR_150_3_04.pdf

Kpan Kpan, K. G., Tiho S., Ehouman, N. M., Touré, M., \& Dembélé A. (2017). Evaluation de la toxicité d'un herbicide à base de 2,4-D sur le vers de terre Eudrilus eugeniae Kinberg, 1867 (Oligochète, Eudrilidae). Revue marocaine des sciences agronomiques et vétérinaires, 5(3), 304-312.

Lavelle, P. (1978). Les vers de terre de la savane de Lamto (Côte d'Ivoire): peuplements, populations et fonctions dans l'écosystème. Doctorat thesis, Université Paris VI, p. 301, 1978.

Lavelle, P., \& Spain, A. V. (2001). Soil Ecology. Kluwer Scientific Publications, Amsterdam, pp. 654.

Lavelle, P., Decaens, T., Aubert, M., Barot, S., Blouin, M., Bureau, F., ... Rossi, J. P. (2006). Soil invertebrates and ecosystem services. European Journal of Soil Biology, 42, 3-15.

Lee, K. E. (1985). Earthworms: their ecology and relationship with soils and land use. New York, p. 411. 
Montgomery, D. R. (2007). Soil erosion and agricultural sustainability. Proceedings National Academy of Sciences of USA, 104, 13268-13272.

Montoroi, J. P. (1997). Conductivité de la solution du sol et d'extrait aqueux de sol: application à un sol sulfaté acide salé de Basse - Casamance (Sénégal). Etude et Gestion des Sols, 4(4), 279-298.

N'guessan, K. A., Diarrassouba, N., Koné, B., Alui, K. A., \& Yao, K. A. (2015). Caractérisation morpho-pédologique et contraintes au développement de Lippia multiflora sur deux sols tropicaux de Côte d'Ivoire. Journal of Animal and Plant Sciences, 24(3), 3814-3828.

Pelosi, C. (2008). Modélisation de la dynamique d'une population de vers de terre lumbricus terrestris au champ. Contribution à l'étude de l'impact de systèmes de culture sur les communautés lombriciennes, Thèse Doctorat à l'université Agro pariTech. p.141, 2008.

Pelosi, C., Barot, S., Capowiez Y., Hedde M., \& Vandenbulcke F. (2014). Pesticides and earthworms. A review, Agronomy for Sustainable Development, 34, 199-228. https://link.springer.com/article/10.1007/s13593-013-0151-z

Pelosi, C., Bertrand, M., Makowski, D., \& Roger-Estrade, J. (2008). WORMDYN: A model of Lumbricus terrestris population dynamics in agricultural fields. Ecological Modelling, 218(3-4), 219-234.

Singh, B., \& Schulze D. G. (2015). Soil Minerals and Plant Nutrition. Nature Education Knowledge, 6(1), 1.

Smeaton, T. C., Daly, A. N., \& Cranwell J. M. (2003). Earthworm population responses to cultivation and irrigation in a South Australian soil. Pedobiologia, 47, 379-385.

Soltner, D. (2000). Phytotechnie générale: les bases de la production végétales. Tome 1: le sol et son amélioration. Sciences et techniques agricoles, 22ème édition, p. 467.

Somasundaram, J., Singh, R.K., Parandiyal A. K., Ali, S., Chauhan, V., K. Sinha, N., ... Simaiya, R. R. (2013). Soil properties under different land use systems in parts of Chambal region of Rajasthan. Journal of Agricultural Physics, 13, 139-147.

Tomas, F. (2004). Vers de terre, les acteurs de la fertilité des sols. Techniques culturales simplifiées, 27(2), 10-21.

Vedie, H. (2008) Fertilité chimique du sol: savoir interpréter les analyses pour gérer les apports d'éléments majeurs (phosphore, potasse, magnésie) en maraîchage biologique. Dossier de fertilité du sol, p. 4, 2008.

Wardle, D. A. (2002). Communities and ecosystems: linking the aboveground and belowground components. Princeton University Press, p. 392.

Zarea, M. J., \& Karimi N. (2011). Effects of herbicides on earthworms. Dynamic soil, Dynamic plant, $\quad 6(1), \quad 15-13$. http://www.globalsciencebooks.info/Online/GSBOnline/images/2012/DSDP_6(SI1)/DSDP_6 
(SI1)5-13o.pdf

Zro Bi, G. F., Yao K. A., \& Kouamé K. F. (2012). Évaluation statistique et spatiale de la fertilité rizicole des sols hydromorphes (gleysols) de la région du Bélier (Côte d'Ivoire). Tropicultura, 30(4), 236-242. http://www.tropicultura.org/text/v30n4/236.pdf

\section{Copyright Disclaimer}

Copyright for this article is retained by the author(s), with first publication rights granted to the journal.

This is an open-access article distributed under the terms and conditions of the Creative Commons Attribution license (http://creativecommons.org/licenses/by/4.0/). 